\title{
FINANCIAL STATEMENTS AND AUDIT IN THE INSURANCE COMPANY
}

\begin{abstract}
In accordance with the Law on Insurance and the Law on Accounting and Audit, insurance companies in Serbia are required to prepare financial statements. These materials are submitted to the Agency of Business Registers and the National Bank of Serbia from $31^{\text {st }}$ December of the reporting year according to the Law on Accounting and Audit. Insurance companies which undergo a change in a legal position, such as mergers, divisions, i.e. sales, have to submit financial statements with a cut-off on the day determined by the decision on the change of a legal position or on the day determined by the sales contract. Furthermore, financial reports are submitted in the cases of the insolvency proceedings or liquidation of an insurance company.

The notion of audit in an insurance company has its importance from the Insurance Law itself, in which the entire Chapter 9 is dedicated to the audit of financial statements. It deals with the performance of the audit, prior consent to the selection of the audit company, liabilities of the audit company, and the check of the audit report and the notification of the body responsible for supervising the audit. ${ }^{1}$ The significance and role of audit in an insurance company is far broader, which will be explored later in this paper.
\end{abstract}

Keywords: Financial analysis, Audit, Control, Insurance companies

* PhD full professor - The Faculty of Economics and Engineering Management in Novi Sad, The University of Business Academy in Novi Sad, e-mail: puzicgoran@gmail.com

1 Zakon o osiguranju [Insurance Act], Službeni glasnik RS, br. 139/14, Art. 182-186. 


\section{Introduction \\ Financial statements in the insurance company}

As in other activities, cash reports in insurance provide an overview of the position of the company and the business changes that have occurred in it. Their goal is to provide information on the financial statement and success of the company, which will be useful for economic decision-making. The reports are therefore of tremendous importance to business owners and management, but also to state supervision, insurers' associations, employees, policyholders, other interested parties, as well as the general public.

Based on the numerous specifics of the insurance industry, financial statements include data on assets, liabilities, equity, income, expenses and cash flows. With regard to international monetary reporting standards, these reports should include income statements, cash flow statement, a statement of changes in equity, necessary remarks and explanations and a statistical appendix. In the continuation of this paper, the most important distinctions of the balance sheet, income statement and cash flow statement will be highlighted.

\section{Balance sheet}

The balance sheet account represents the balance of the insurer's assets assets (market value of assets, mainly investments in bonds, shares, real estate or loans), and capital and liabilities - liabilities at the beginning and end of the accounting period. ${ }^{2}$

Cut-off days are usually $31^{\text {st }}$ March, $30^{\text {th }}$ June, $30^{\text {th }}$ September, and $31^{\text {st }}$ December. Generally, the annual balance is of greatest importance. Changes in individual balance sheet items occur due to different business flows within the company. As a rule, the largest items within assets in insurance companies are fixed and current assets, and within liabilities is capital.

Compared to other activities, balance sheets in insurance are characterized by important features. As pointed out earlier, the share of investments in assets is significant because insurance companies are important investors in the financial market. Significant liabilities towards policyholders are reflected on the liabilities side, which can be monitored through items such as unearned premium (part of the collected premium which will turn into income in the future accounting period) and unpaid claims (estimated expenses for incurred

\footnotetext{
${ }^{2}$ Tepavac, R., Njegomir, V. (2016). Ekonomika osiguranja, [Insurance economics]. Novi Sad, Fakultet za ekonomiju i inženjerski menadžment, p. 230.
} 
claims in the current accounting period which are to be paid in the future period). ${ }^{3}$ It is also important to emphasize that some items on the liabilities side in insurance companies are determined in a special way. This refers to the mathematical reserve in life insurance (the long-term provisions of items in liabilities), unearned premiums and reserved claims (items in accruals and deferred income).

Unpaid subscribed capital is registered based on the buyer's statement that s/he will pay funds for the purchasing of the insurance company's shares. Thereupon, once the payment has been made, this item is closed. Intangible assets include patents, licenses and similar rights, multi-year leases, investments in capital assets and intangible asset down payment.

Special attention has been given to the item of company's reputation. It represents a type of intangible property that provides the possibility of good earnings due to its name, i.e. the company's brand for many reasons: good management, built relationships with customers, technological superiority, high performance, weak competition, good business practices, favorable spatial position. It is accounted for when the investor purchases the entire insurance company and pays a price that exceeds the regular market value.

Table 1. Simplified layout of the the insurer's balance sheet. ${ }^{4}$ (as of $31^{\text {st }}$ December, 2019.)

RSD thousands

\begin{tabular}{|l|c|c|c|}
\hline item & current year & previous year & index \\
\hline \multicolumn{4}{|l|}{ ASSETS } \\
\hline A. Fixed assets-investments & 7.800 .000 & 5.995 .000 & 130,11 \\
\hline - unpaid subscribed capital & 100.000 & 200.000 & 50,00 \\
\hline - intangible assets (properties) & 200.000 & 95.000 & 210,53 \\
\hline - reputation of the company & - & - & - \\
\hline - real estate, plants, equipment & 4.000 .000 & 3.800 .000 & 105,26 \\
\hline - long-term cash investments & 3.500 .000 & 1.900 .000 & 184,21 \\
\hline B. Current assets-receivables & 6.010 .000 & 5.012 .000 & 119,91 \\
\hline - supplies & 10.000 & 12.000 & 83,33 \\
\hline
\end{tabular}

\footnotetext{
${ }^{3}$ Lukić, R. (2012). Računovodstvo osiguravajućih kompanija [Accounting of insurance companies]. Beograd, Centar za izdavačku delatnost Ekonomskog fakulteta u Beogradu, p. 103.

${ }^{4}$ Aćimović, S. (2010). Ekonomski rečnik [Economic Dictionary]. Beograd, Centar za izdavačku delatnost Ekonomskog fakulteta u Beogradu, p. 260.
} 


\begin{tabular}{|c|c|c|c|}
\hline $\begin{array}{l}\text { - fixed assets intended for sale } \\
\text { and suspended assets }\end{array}$ & - & - & - \\
\hline $\begin{array}{l}\text { - short-term receivables, } \\
\text { investments and cash }\end{array}$ & 6.000 .000 & 5.000 .000 & 120,00 \\
\hline V. Business assets $(A+B)$ & 13.800 .000 & 10.995 .000 & 125,51 \\
\hline $\begin{array}{l}\text { G. Loss above the amount of } \\
\text { capital }\end{array}$ & - & - & - \\
\hline D. Total assets $(V+G)$ & 13.800 .000 & 10.995 .000 & 125,51 \\
\hline Đ. Off-balance sheet assets & 400.000 & 500.000 & 80,00 \\
\hline \multicolumn{4}{|l|}{ LIABILITIES } \\
\hline A. Capital and reserves & 4.800 .000 & 3.995 .000 & 120,15 \\
\hline - basic and other capital & 2.900 .000 & 2.500 .000 & 116,00 \\
\hline - unpaid subscribed capital & 100.000 & 200.000 & 50,00 \\
\hline - reserves & 400.000 & 300.000 & 133,33 \\
\hline - revaluation reserves & - & - & - \\
\hline - undistrubuted profit & 1.400 .000 & 995.000 & 140,70 \\
\hline - loss up to the amount of capital & - & - & - \\
\hline - repurchase of own shares & - & - & - \\
\hline B. Provisions and liabilities & 9.000 .000 & 7.000 .000 & 128,57 \\
\hline - long-term provisions & 800.000 & 850.000 & 94,12 \\
\hline - long-term liabilities & 50.000 & 100.000 & 50,00 \\
\hline - short-term liabilities & 1.000 .000 & 600.000 & 166,67 \\
\hline $\begin{array}{l}\text { - accrued costs and deferred } \\
\text { revenue }\end{array}$ & 7.050 .000 & 5.355 .000 & 131,65 \\
\hline - deferred tax liabilities & 100.000 & 95.000 & 105,26 \\
\hline V. Total liabilities $(\mathrm{A}+\mathrm{B})$ & 13.800 .000 & 10.995 .000 & 125,51 \\
\hline G. Off-balance sheet liabilities & 400.000 & 500.000 & 80,00 \\
\hline
\end{tabular}

Source: Žarković, N. (2008). Ekonomika osiguranja [Insurance economics]. Beograd, Univerzitet Singidunum, p. 127.

Accruals are accounts whose task is to contribute to a more accurate and justifiable distribution of assets and liabilities by accounting periods, primarily due to the time mismatch between revenues and expenses on the one hand, and payments and disbursements on the other. ${ }^{5}$ Prepayments and accrued in-

\footnotetext{
${ }^{5}$ Aćimović, S., op. cit., p. 893.
} 
come in the insurance company's balance sheet are included under item B in the assets "Current assets - receivables", sub-item "Short-term receivables, investments and cash". Accrued costs and deferred revenues are a special subitem of liabilities B "Provisions and liabilities".

Both sides of these balance sheets, namely assets, specified in assets, and sources of assets, specified in liabilities, must have the same value on the balance sheet cut-off day. The same phenomenon is observed, but with two different accounting points of view.

\section{Income statement}

As with any company, the insurance company's income statement consists of revenues, expenses and final business productivity. As opposed to balance sheet, which represents the balance at the cut-off day, the income statement relates to a period. The most significant is the annual balance sheet; nevertheless quarterly and even monthly balance sheets are also compiled. If the joint-stock insurance company manages to achieve a balanced movement of total revenues and expenses, a profit can be expected. Otherwise, a loss is recorded. A mutual insurance company shows a surplus or shortage of funds.

Although certain distinctions arise from the insurance activity itself, the general principles that apply to the preparation of the income statement in other activities also apply in insurance. As with the balance sheet, the income statement must be balanced. If the income is equal to the expenses, the insurer did not make a profit in the long run and when the expenses are higher than the income, the survival of the insurance company will be endangered. The goal of the insurance company is to achieve higher income from expenses, and the other two cases are acceptable only in the short term. ${ }^{6}$

With regards to income, the most important items with the insurers are usually the following:

- insurance premium,

- interest income,

- claims collected from reinsurance.

The income item of insurance premium differs from the calculated premium as an insurance business indicator. It is determined by a reduction for the transferable premium reserves for the following year and an increase for the yield premium from the previous year, as well as a reduction in the amount

${ }^{6}$ Tepavac, R., Njegomir V., op. cit., pp. 241-242. 
of calculated insurance tax. Undoubtedly, with our insurers, the insurance premium has the largest amount and share in profit.

The item interest income incorporates interest on the basis of various forms of investment of surplus funds available to the insurer and interest on unpaid premiums charged to non-paying policyholders. Claims collected from reinsurance include inflows from domestic and foreign reinsurers when the risks covered by this type of protection are realized.

Principally, the volume of expenditures with insurers is determined by the occurrence of the danger and the resulting compensation, i.e. claims reserves. The next important expenditure item are insurance costs (tangible and intangible expenditures).

Also, significant factors on the expenditure side are reinsurance premiums and allocations for the measures which would prevent the occurrence of harmful events.

Table 2. Simplified layout of the income statement with insurers (for the period $1^{\text {st }}$ January $-31^{\text {st }}$ December of second- year)

RSD thousands

\begin{tabular}{|l|c|}
\hline Insurance premium & +1.000 .000 \\
\hline Claims collected from reinsurance & +250.000 \\
\hline Damages & -650.000 \\
\hline Reserved damages & -100.000 \\
\hline $\begin{array}{l}\text { Allocation for measures which would prevent the occurrence } \\
\text { of harmful events }\end{array}$ & -50.000 \\
\hline Reinsurance premium paid & -150.000 \\
\hline Insurance costs & -250.000 \\
\hline Insurance profits & +50.000 \\
\hline Interest income & +60.000 \\
\hline Total profit before tax & +110.000 \\
\hline Income tax & -20.000 \\
\hline Net profit & +90.000 \\
\hline
\end{tabular}

Source: Žarković, N., op. cit., p. 129.

Examination of the causes that determine the achieved business performance enables undertaking of the measures which would increase the insurance company's profit. Due to distinctions of the insurance business, it is difficult or impossible to influence the factor of occurrence of danger 
and occurrence of damages. However, there are a number of measures that create space for profit improvement: reducing the premium to policyholders for years without claims, charging additional premiums to those policyholders who often experience damages, savings in insurance costs, establishing companies similar to insurance, more accurate assessment of necessary risks which are required to be transferred into reinsurance. ${ }^{7}$

When the cumulative monetary indicators of insurers' operations are observed at the state level, it can be noticed that one and the same company can have a relatively small share in the total profit of all insurers in the country, and far larger shares in balance sheet assets and capital. On the other hand, some companies have significant shares in profit and lower indicators related to balance sheet assets and capital. The difference, i.e. the relatedness of these participations, arises from the fact that "in insurance business, only the net profit does not reflect the actual volume of the insurance company's success in a certain year". ${ }^{8}$

\section{Cash flow statement}

The statement of cash flows created by each insurance company represents one of the basic financial statements. As pointed out, its structure is a legal obligation. The statement of cash flows demonstrates the inflows, outflows and changes in the state of cash resulting from business and financial activities, and investments in a certain period. The cash flow indicates where the money comes from, what it is used for and how much the account balance has changed.

Due to the special characteristics of the insurance business, and in order to create a better picture of the financial position of the company, while observing the overall cash flow, it is necessary to take into account insurance liabilities and their maturity, as well as investments of insurance funds, since they are usually set to cover liabilities. However, in order to have a complete insight into the overall business of the insurer, it is necessary to consider other accounting reports along with the cash flow. ${ }^{9}$

\footnotetext{
${ }^{7}$ Lukić, R., op. cit., pp. 100-101.

${ }^{8}$ Zarkovic, N. (2006). Insurance in Serbia 2004-2006, Survey Republic of Serbia, 47 (2), p. 97.

${ }^{9}$ Žarkovic, N. (2013). Pojmovnik osiguranja [Insurance glossary]. Novi Sad, Skonto, p. 549.
} 


\section{Audit in insurance}

As in other activities, audit in insurance involves a review of the financial statements and books of accounts in order to determine their reliability, unbiasedness, and compliance with legal regulations and established accounting principles. Independent experts - auditors - are in charge of giving appropriate assessments in the reports. There is an external audit (performed by foreign experts) and an internal audit (performed by experts employed by the insurance company). This paper deals with this second viewpoint.

\section{Fundamentals of internal audit in insurance}

The main reason for the existence of internal audit is the fact that it can cover an important shortcoming of external audit. Namely, the latter usually acts subsequently, when business events have already occurred, while internal audit can contribute to the accuracy of business performance presentation and the work of the company itself. ${ }^{10}$

As a rule, internal audit in the insurance industry in the world is thoroughly regulated. The same applies to domestic legislation. Starting from the magnitude of the insurance company, and the complexity and scope of internal audit work, our regulations provide three possibilities:

1. to be performed by an individual - internal auditor,

2. to be conducted as part of a special company unit,

3 . to be conducted through a board of auditors.

An individual dealing with internal audit has a limited role, especially if it is an insurance company with a branched business that deals with several types of insurance. Furthermore, the board of auditors as a replacement for the supervisory board in our country is not widespread. Hence, internal audit in insurance usually exists as an independent and separate entity in the company.

Every business system, including the insurance business system, consists of a management, contractor, intelligence and supervisory sub-unit. The supervisory subsystem should play a significant role in identifying deficiencies in the company and making recommendations for solutions to rectify them.

\footnotetext{
${ }^{10}$ Slović Krčadinac I. (2004). Revizija u osiguranju [Insurance audit]. Beograd, Fineks, p. 19.
} 
However, the number of Serbian companies in which the supervisory subsystem is well regulated and where it fulfills tasks well is very small. ${ }^{11}$

Provisions such as: supervision, inspection, audit, accounting, etc. increasingly appear in legal regulations in Serbia. Therefore, it is necessary to differentiate these expressions. In foreign sources in this field, a distinction is first made between supervision, on the one hand, and inspection of work, i.e. audit, on the other. Supervision is seen as a complex activity of assessing the regularity of the company's operations and issuing orders to eliminate irregularities that are not in accordance with regulations and other external and internal rules. This makes an invaluable contribution to the prevention or reduction of unregulated and impermissible phenomena in work. Insurance supervision is carried out by external, state bodies (in our country, the National Bank of Serbia).

Although supervision is often considered identical with inspection and audit, according to the theoretical understanding, supervision is a higher term, while inspection and audit are lower-order terms.

Inspection and audit have common characteristics - inspection of work process parts, comparison of documents and actions taken by the company with regulations in order to prevent irregularities and illegalities in the business of the business entity. It is not always easy to differentiate them because they both fall into the field of business supervision. ${ }^{12}$

However, performance checks and audit differ in important factors. The differences are pointed out by questions:

- executors or persons in charge of performing one or another procedure,

- level of expertise, i.e. required training,

- the existence or non-existence of supervisory bodies involved in these actions,

- frequency of implementation of prescribed inspection and audit activities,

- the manner of performing these tasks, i.e. work procedures.

11 Mićić, Lj. (2007). Rukovođenje internom revizijom u osiguranju, [Internal Audit Management in Insurance]. Finansije, bankarstvo, revizija, osiguranje, 4 (2), p. 100.

${ }^{12}$ Vujović, V. (2006). Mišljenje sa rezervom [Opinion with reservation]. Ekonomska politika, 27. februar, p. 13. 


\section{Categorization of labour inspections in the insurance company}

Generally, inspection of the insurance company's labour implies examining whether certain behaviors, methods and procedures in it are harmonized with certain criteria, i.e. requirements. It has to be permanent and based on professional or scientific grounds.

Normally, labour inspection is present in companies in all countries, regardless of the degree of their development and the form of government. A certain type of inspection of economic entities also existed in socialism. In developed capitalism, when the role of the owner is separated from the manager of the company, it becomes a regular form of action. Primarily, it refers to bookkeeping records and reports.

There are a large number of labour check divisions in insurance and other companies. They are based on different criteria. The most important types of checks include: ${ }^{13}$

1. external and internal verification,

2. direct and indirect verification,

3. accounting and management audit,

4. prevention and suppression check,

5. external and substantive verification.

1. External verification shall be performed by persons who are not employed by the insurance company. It is most often carried out by the state bodies through checks as special working bodies. In terms of time, the external audit falls under the subsequent audit, as it examines the completed business changes in certain sections of the company's work.

2. Internal verification is carried out by the employees of the insurance company. It consists of all forms of internal audits which are different from internal accounting audits. Essentially, the scope of internal audits also includes accounting and management audits with exclusively internal features. In our legislation, internal check is most often mentioned.

3. Direct verification represents such examination by which each original document is verified. It is evident that such a check can be

\footnotetext{
${ }^{13}$ Mićić, Lj., op. cit., p. 101.
} 
carried out only with a smaller volume of business changes, because it requires more time and produces higher costs.

4. Indirect verification represents research according to the method of a randomly selected sample, i.e. verification based on aggregate data from the same type of work procedures, for example, resolving claims from one branch of insurance.

5. The persons employed in the company's accounting department are in charge of the accounting audit. In essence, the accounting audit is always ongoing because the accounting staff always performs it during the regular duration of the work process. ${ }^{14}$ Management audit includes all types of ongoing audits that do not fall under the accounting audit. The current examination of the insurance company's general management achieves a verification of the entire system's division.

6. The check for prevention is carried out in order to avoid deviations from the prescribed business rules of the insurance company.

7. The check for suppression follows when violations of the prescribed rules have occurred with a high degree of probability.

8. The external verification aims to assess the measure of compliance with all principles of flow and renewal of documents that accompany the work of the company. This check always precedes the substantive check. It refers to past business operations.

Substantive verification examines the essential and substantive accuracy of business ventures. Unlike external verification, it may refer to both past and future endeavors.

\section{Internal audit tasks in the insurance company}

According to our regulations, each insurance company is obliged to establish a special part that will deal with the internal audit of the company's operations and which will be independent and autonomous in performing its work. That part of the company is directly subordinated to the supervisory board to which it reports to and regularly submits reports to it. Other bodies of the insurance company, as well as employees, are prohibited from preventing, restricting or hindering the work of employees in internal audit. ${ }^{15}$

\footnotetext{
${ }^{14}$ Zakon o računovodstvu i reviziji [Law on Accounting and Auditing], Službeni glasnik RS, 46/06, 111/09, Art. 9.

${ }^{15}$ Zakon o osiguranju [Insurance Act], op. cit., Art. 154.
} 
The following tasks are assigned to the internal audit of the insurance company:

1. continuous monitoring, verification and improvement of the work system in the company,

2. assessment of the risk management organization to which the insurance company is exposed, i.e. which can be assumed to be endangered,

3. assessment and evaluation of the established manner of the company's internal audit performance. This includes procedures and actions which the management of the insurance company is obliged to carry out in a manner appropriate to the nature, complexity and hazards of work, or changes in business conditions that can be foreseen, in order to prevent irregularities and illegalities in business,

4. issuing recommendations for the elimination of observed irregularities and shortcomings in the work, and for the improvement of work procedures.

The insurance company's internal audit department monitors and evaluates:

1. adequacy and implementation of prescribed risk control policies and procedures,

2. accounting procedures and organization of work in accounting,

3. reliability and speed of creating monetary and management information.

The conduct of internal audit is regulated by a rulebook issued by the board of directors of the insurance company. Through the rules and work program, the company is obliged to ensure that the operations of this department are in accordance with the principles of the profession and the customs of internal audit, international standards in this area, and with appropriate moral principles.

In order to perform internal audit activities, an insurance company must have at least one internal auditor. The company is obliged to determine the conditions for the appointment (and dismissal) of this person, as well as the schedule of other employees (if any) in the internal audit department. The internal auditor is prohibited from performing other tasks in the company. He has no authority or responsibility for the preparation of files and other documents that may be subject to audit. 
The annual work plan of the internal audit includes the planned activities, primarily the business areas of the insurance company that will be subject to inspections and deadlines for the completion of the planned actions.

Regardless of the program and work plan, the internal audit may in individual cases perform an extraordinary review of operations, based on the request of the management (assembly or supervisory board).

Recognizing the importance of the insurance business and its impact on cash flows in the country, insurance supervision is stricter and more comprehensive than in many industries. Internal audit is the first step in it, followed by external audit and supervision by the National Bank of Serbia. ${ }^{16}$

\section{Reporting by internal audit}

The insurance company's Internal Audit Department compiles quarterly and annual reports.

Generally, the quarterly internal audit report contains: ${ }^{17}$

1. a description of the performed examinations of the company's work, i.e. the subject of the audit,

2. assessment of the manner of processing documents and procedures for concluding insurance contracts, issuing policies and resolving claims,

3. illegalities and other irregularities - if they were noticed in the audit procedure, with explanations and consequences of the identified irregularities, with the designation of responsible persons,

4. proposal of measures for elimination of observed irregularities and deadlines for their implementation,

5. other findings, assessments and proposals regarding the elimination of irregularities established by the internal audit.

The annual internal audit report is, undeniably, more extensive. In addition to everything stated for the quarterly report, it also encompasses the following items:

1. report on the implementation of the work program and the annual work plan of the internal audit,

2. summary of significant findings from the performed audit,

\footnotetext{
${ }^{16}$ Vujović, V., op. cit., p. 16.

${ }^{17}$ Zakon o osiguranju [Insurance Act], op. cit., Art. 158.
} 
3. assessment of the measures taken to eliminate the established irregularities.

The Internal Audit Department is obliged to submit both quarterly and annual reports to the Supervisory Board of the insurance company. The company's Supervisory Board reviews the annual internal audit report at the same time as the insurance company's annual financial report. The Supervisory Board is obliged to submit the annual internal audit report to the General Meeting of Shareholders. The report regarding the findings of the internal audit on the measures taken and the supervisory board to eliminate the observed irregularities in the work is also submitted

Internal audit reporting does not always have to adhere to the stated deadlines, i.e. reports. If the Department responsible for these affairs discovers that the insurance company does not act in accordance with the rules on risk management regarding the application of co-insurance and reinsurance institutions, payment of claims, maintenance of payment, amount of share capital, technical reserves, guarantee reserves, investment of these funds, etc. ${ }^{18}$ Which, in essence, endangers the interests of the insured, it shall immediately, and no later than twenty-four hours from the moment of knowledge, inform the supervisory board.

\section{Conclusion}

The subject of research in this paper was financial reports and audit in the insurance company. The three most important financial reports were processed - the balance sheet, income statement and cash flow statement, which insurance companies are obliged to compile and submit to the competent state bodies. In addition to the general characteristics of these materials, which are the same in many activities, the focus was on emphasizing the specifics and differences in the insurance industry. In addition to showing the business and financial position, as well as all business changes that have occurred in the insurance company, these reports are used not only by the management itself to make more authoritative and thorough decisions, but also by the environment - primarily supervision, other persons and the general public.

This paper also emphasizes the importance of audit in work, understood as an inspection of the accuracy of accounts and work of the insurance company. Whether voluntary or imposed by law, an audit in insurance involves a

${ }^{18}$ Zakon o osiguranju [Insurance Act], op. cit., Art. 149. 
thorough assessment of the validity of the company's financial statements and its operations. In particular, the items in the insurer's balance sheet (assets and liabilities), and in the income statement (profit and loss account) are checked as the basic financial statements that accompany each business year. In Serbia, an audit is required by law for all insurance companies. It is performed by external auditors who compile a detailed audit report, but also by the internal audit in the insurance company, which has a wider range of work, because it supervises the entire scope of the company's business. In addition, the audit institution has an extremely important role in the implementation of state supervision over insurance, which is assigned to the National Bank of Serbia.

\section{Puzić Goran}

Dr, Redovan professor, Fakultet za ekonomiju i inženjerski menadžment, Univerzitet Privredna akademija, Novi Sad

\section{FINANSIJSKI IZVEŠTAJI I REVIZIJA U OSIGURANJU}

REZIME: U skladu sa Zakonom o osiguranju i Zakonom o računovodstvu i reviziji, osiguravajuća društva u Srbiji dužna su da pripreme finansijske izveštaje. Ovi materijali se dostavljaju Agenciji za privredne registre i Narodnoj banci Srbije od 31. decembra izveštajne godine, u skladu sa Zakonom o računovodstvu i reviziji. Osiguravajuća društva koja prolaze kroz pravni položaj, poput spajanja, podele, odnosno prodaje, moraju da podnesu finansijske izveštaje sa presekom na dan utvrđen odlukom o promeni pravnog položaja ili na dan utvrđen prodajom ugovora. Pored toga, finansijski izveštaji se podnose u slučajevima insolventnosti ili likvidacije osiguravajućeg društva. Pojam revizije u osiguravajućem društvu ima značaj iz samog Zakona o osiguranju, u kojem je celo poglavlje 9 posvećeno reviziji finansijskih izveštaja. Bavi se obavljanjem revizije, prethodnom saglasnošću za izbor revizorske kuće, obavezama revizorske kuće i proverom izveštaja o reviziji i obaveštenjem tela odgovornog za nadzor revizije. Značaj i uloga revizije u osiguravajućem društvu su daleko širi, što će biti istraženo u ovom radu.

Ključne reči: finansijska analiza, revizija, kontrola, osiguravajuća društva 


\section{References}

1. Aćimović, S. (2010). Ekonomski rečnik [Economic Dictionary]. Beograd, Centar za izdavačku delatnost Ekonomskog fakulteta u Beogradu

2. Lukić, R. (2012). Računovodstvo osiguravajućih kompanija [Accounting of insurance companies]. Beograd, Centar za izdavačku delatnost Ekonomskog fakulteta u Beogradu

3. Mićić, L. (2007). Rukovođenje internom revizijom u osiguranju, [Internal Audit Management in Insurance]. Finansije, bankarstvo, revizija, osiguranje, 4 (2), pp. 99-110

4. Slović Krčadinac, I. (2004). Revizija u osiguranju [Insurance audit]. Beograd, Fineks

5. Tepavac, R., Njegomir, V. (2016). Ekonomika osiguranja [Insurance economics]. Novi Sad, Fakultet za ekonomiju i inženjerski menadžment, Novi Sad

6. Vujović, V. (2006). Mišljenje sa rezervom [Opinion with reservation]. Ekonomska politika, 27. februar, pp. 13-14

7. Zakon o osiguranju [Insurance Act], Službeni glasnik RS, 139/14

8. Zakon o računovodstvu i reviziji [Law on Accounting and Auditing], Službeni glasnik $R S, 46 / 06,111 / 09$

9. Zarkovic, N. (2006). Insurance in Serbia 2004-2006, Survey Republic of Serbia, 47 (2), pp. 85-98

10. Žarković, N. (2008). Ekonomika osiguranja [Insurance economics]. Beograd, Univerzitet Singidunum

11. Žarković, N. (2013). Pojmovnik osiguranja [Insurance glossary]. Novi Sad, Skonto 